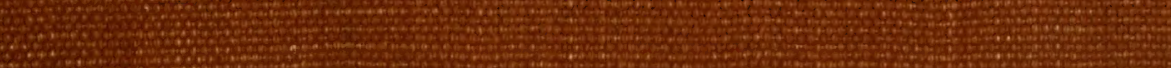
20.5.

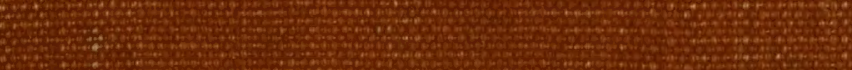
2.
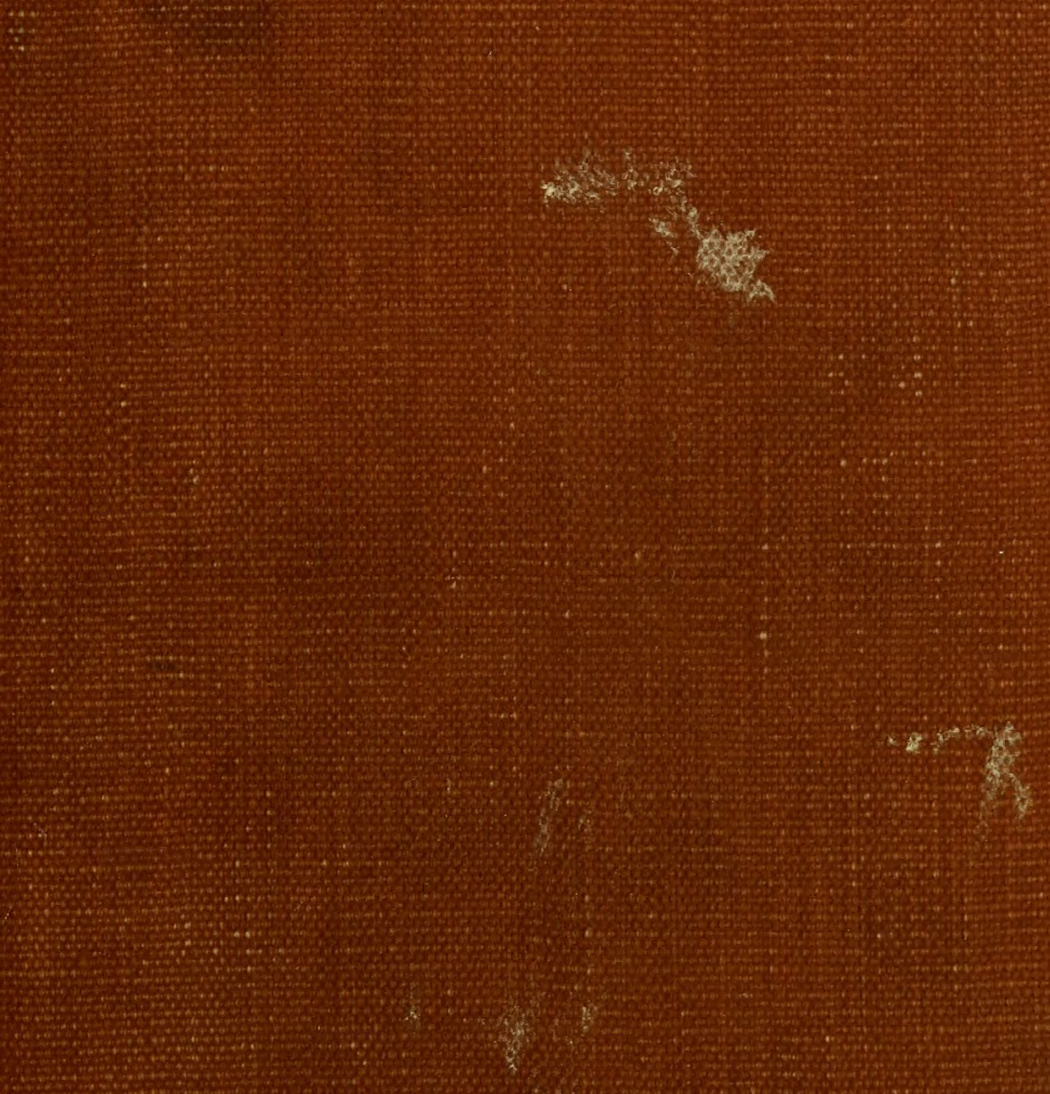


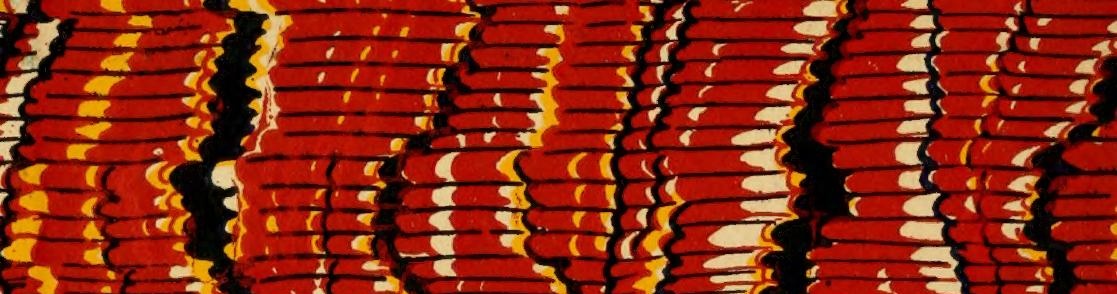

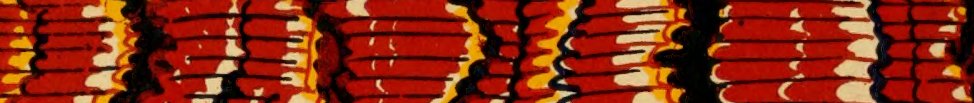

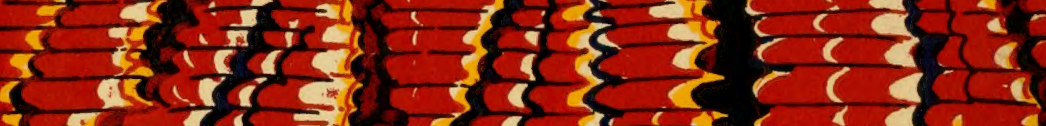

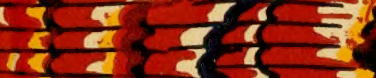

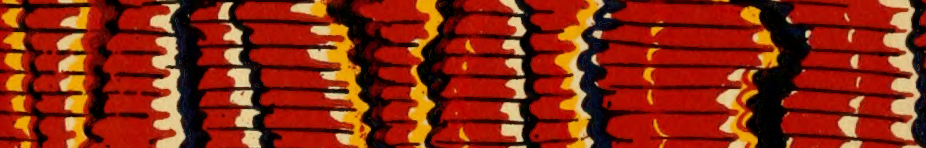

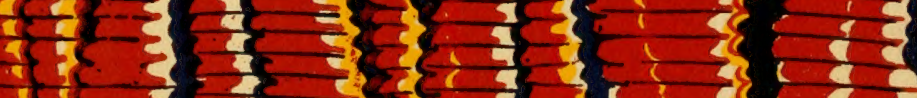

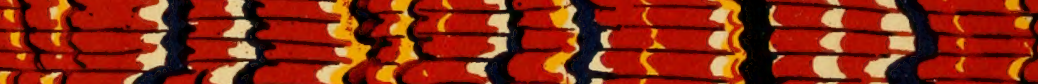

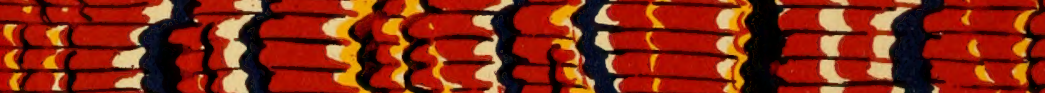

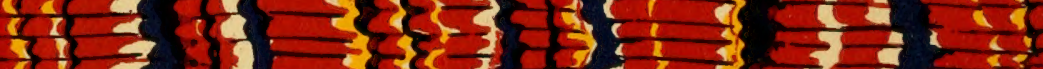

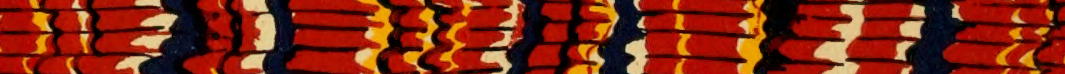

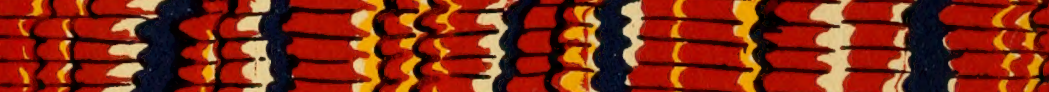

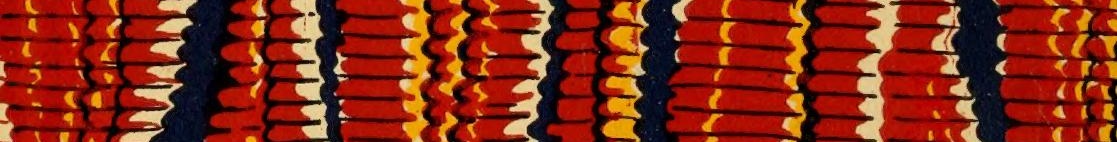

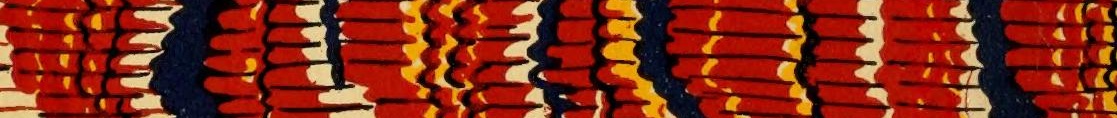

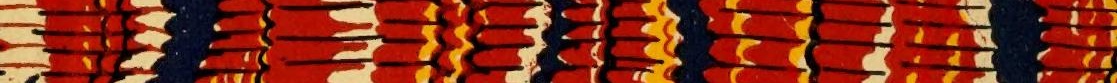

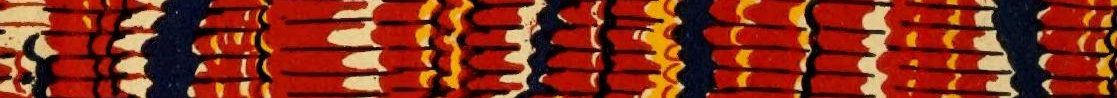

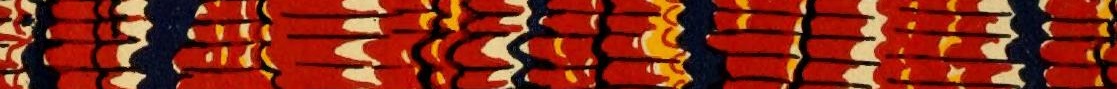

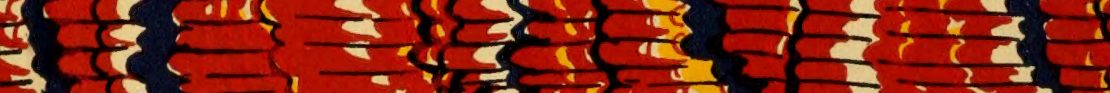

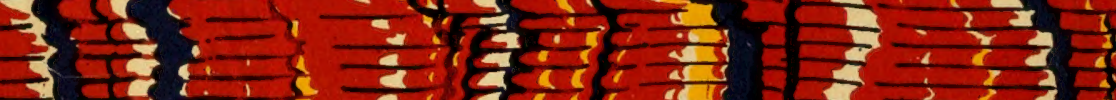

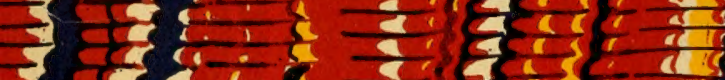

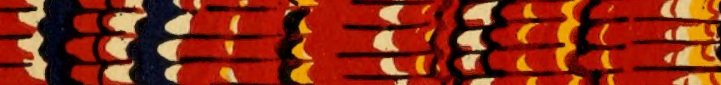

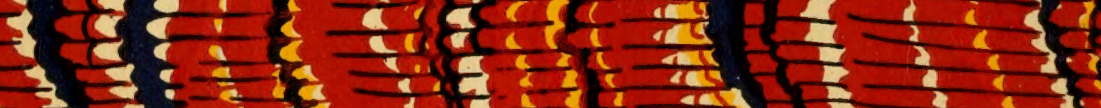

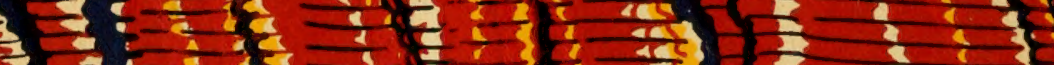

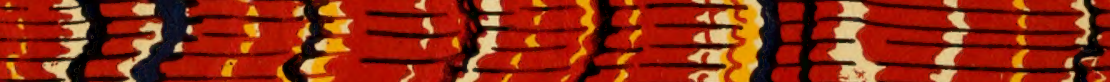

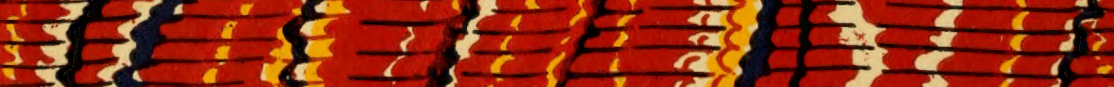

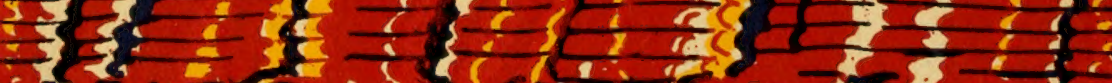

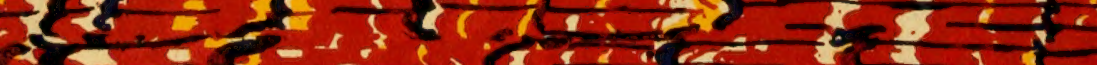

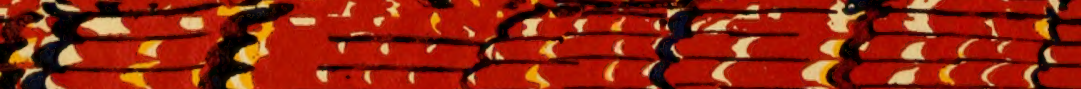

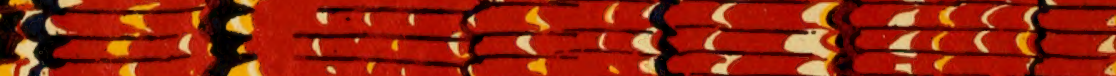

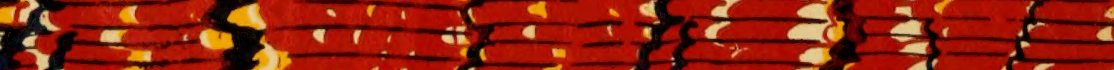
दै वे अं। 

From the Annals and Magazine of Natural History, Ser. 7, Vol. xi., April 1903.

British Land Tsopoda.-Supplement. By Canon A. M. Norman, F.R.S. \&c.

Is the 'Annals' for January 1899 (ser. 7, vol. iii. p. 70) I published a paper containing notes on all the Land Isopoda known to belong to our fauna up to that date. Three species have since been added, which I will now notice, with some other brief remarks.

Genus Trichoniscus, Brandt.

Trichoniscus vividus (Koch).

Dr. Scharff has recorded this species from Cappagh, Co. 
Waterford ('Irish Naturalist,' vol. ix. p. 158), and has kindly sent me specimens from another locality, viz. Borris, Co. Carlow. It has not as yet been found in England.

\section{Genus Haplophthalmus, Schöbl.}

\section{Haplophthalmus Mengii (Zaddach).}

1844. Itea Mengii, Zaddach, Synops. Crust. Prussic. Prodromus, p. 16. 1860. Haplophthalmus elegans, Schöbl, Zeits. f. wiss. Zool. vol. x. p. 449.

1885. Haplophthalmus Mengii, Budde-Lund, Crust. Isop. Terrestria, p. 250.

1898. Haplophthalmus Mengii, G. O. Sars, Account of Crustacea of

Norway, vol. ii. Isopoda, p. 167, pl. lxxiv. fig. 1.

I found two specimens of this small but most strongly characterized addition to our fauna in 1900 at Corcumroe Abbey, Co. Clare, Ireland. The abbey is a ruin and in a most lonely spot. 'The Haplophthalmi were met with under a piece of moss growing on an old tombstone. I was very anxious to find more, but a long search produced no further specimens.

\section{Genus Porcellio, Latreille.}

Porcellio Ratzeburgii, Brandt.

1833. Porcellio Ratzeburgi, J. F. Brandt, Conspectus Monog. Crust. Oniscodorum Latreillii, p. 13.

1885. Porcellio Ratzeburgii, Budde-Lund, Crust. Isop. Terrest. p. 83.

1898. Porcellio Ratzeburgi, G. O. Sars, Crust. Norway Isopoda, p. 182, pl, lxxx. fig. 1.

It is also $P$. nemorosus, Koch, $P$. quercuum, Schnitzer, and probably $P$. lugubris, Koch.

In $1899 \mathrm{Mr}$. W. M. Webb sent me some specimens of this species from Essex to determine. They were only young examples, but seemed clearly referable to $P$. Ratzeburgii (see Webb, 'Essex Naturalist,' vol. xi. 1899, p. 127). I have taken the species commonly in the Tyrol, at Trafoi, St. Martini, and Capitello.

\section{Porcellio dilatatus, Brandt.}

I have found this species at Berkhamsted, Herts. In Ireland Dr. Scharff has recorded it from Dundrum, and Mr. C. W. Buckle writes respecting it ('Irish Naturalist,' vol. xi. 1902, p. 43) :- "Occurs abundantly in outhouses in Antrim Road, Belfast." He says that he has also received it from near Dunmurray, Co. Antrim, and adds, "I have also taken it near Chichester, Sussex." 


\section{Genus Armadillidium, Brandt.}

Armadillidium vulgare (Latreille).

Dr. Scharff, in his paper on "The Irish Woodlice" ("Irish Naturalist,' vol. iii. 1891), wrote of this species:-" In Ireland it is more common in the plains than in the mountains, and it has not been taken on the west coast." Remembering this, when in Galway in 1900 I sought for the species whereever I was, but saw nothing of it in the north; but in the south of the county I met with it in some numbers at Ardrahan.

Armadillidium pulchellum, Zencker.

_-? Oniscus pulchellus (Zencker), Panzer, Heft 62. 21 (fide BuddeLund).

1833. Armadillidium pulchellum, J. F. Brandt, Conspectus Monog. Crust. Onisc. Latr. p. 26.

1885. Armadillidium pulchellum, Budde-Lund, Crust. Isop. Terrest. p. 70 .

1892. Armadillidium pulchellum, A. Dollfus, "Tableaux synoptiques de la Faune Française : Le genre Armadillidium," Feuille des Jeunes Naturalistes, iii. série, 1892, p. 14 (separate copy) and woodcuts.

1898. Armadillidium pulchellum, G. O. Sars, Crust. Norway Isop. p. 191, pl. lxxxiii. fig. 4.

1900. Armadillidium pulchellum, Scharf, Irish Naturalist, vol. x. p. 109.

This is the third addition to our fauna made since my previous paper was published. I have received from Dr. Scharff specimens which were found at Sligo.

Dr. Kinahan, in his first paper on the British Land Isopoda (Nat. Hist. Review, vol. iv. 1857, p. 258), mentioned that twelve out of the fourteen species he then recorded had been found in his garden, not 60 yards square, at Dublin. Gardens, in fact, are especially favourable hunting-grounds for woodlice. In my own here, and even in the part nearest to my house (separated by a fence from a farther garden), which is of about an acre in extent, I have found ten species. It may be of interest to note the woodlice found under similar circumstances by Dr. Kinahan and myself. I use present nomenclature and place the names employed by Dr. Kinahan in brackets.

Garden at Dublin (Dr. Kinahan's) :-Trichoniscus pusillus (Philourgria celer); Uniscus asellus (U. murarius and fossor); Philoscia muscorum; Metoponorthus pruinosus (Porcellio pruinosus); Metoponorthus cingendus (Porcellio cingendus); Porcellio scaber, lavis, pictus, and dilatatus; Cylisticus convexus (Porcellio armadilloides); Armadillidium vulgare. 
Garden, Red House, Berkhamsted, Herts :-Haplophthalmus danicus; Trichoniscus pusillus and roseus; Oniscus asellus; Philoscia muscorum; Platyarthrus Hoffmanseggii; Metoponorthus pruinosus; Porcellio scaber; Cylisticus convexus; Armadillidium vulgare.

In my former paper at the bottom of p. 75 -in consequence of a wandering mind, I suppose-the word "Porcellidium" is substituted for Armadillidium. 



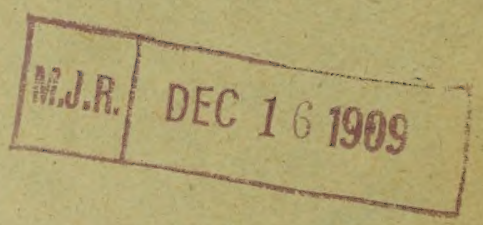







I $35=3,3=53=$

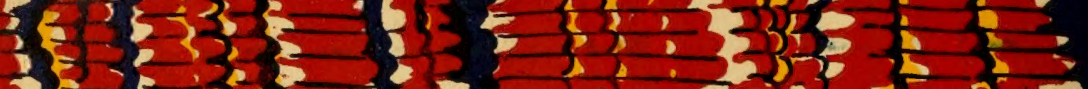
35352,303 $3=3: 3:-35$ 3 औ $35-3=3$ :

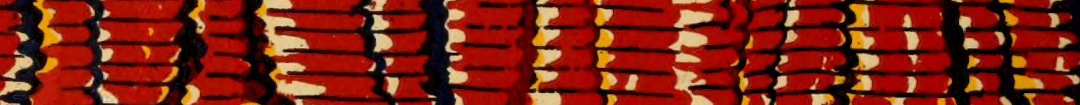

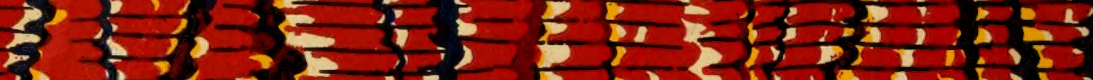

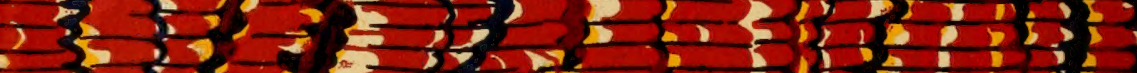

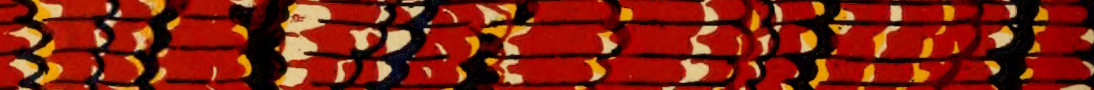

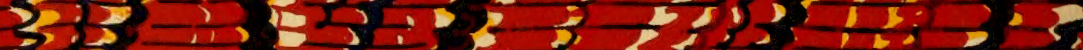

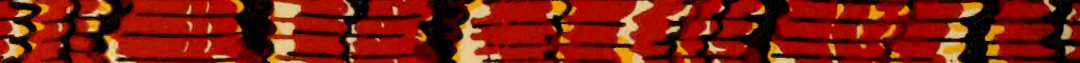

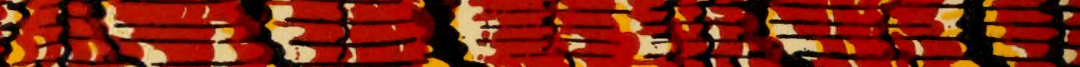

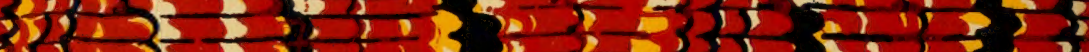

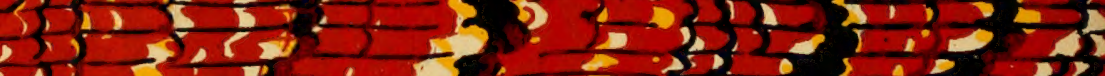

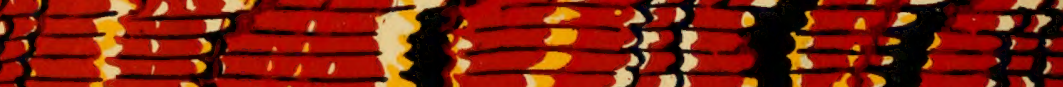

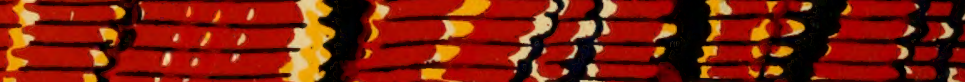

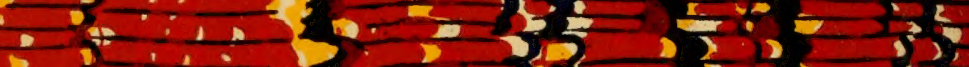

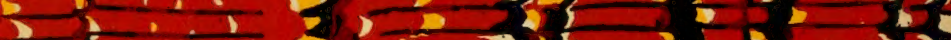

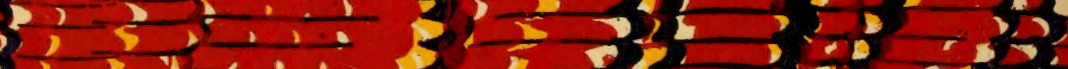

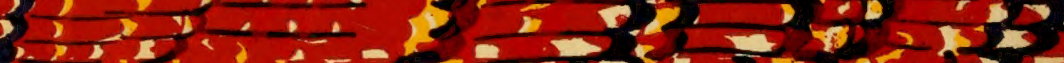

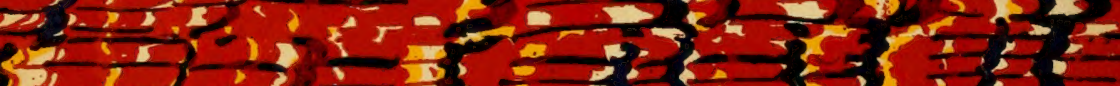

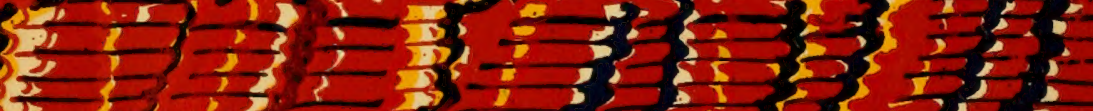

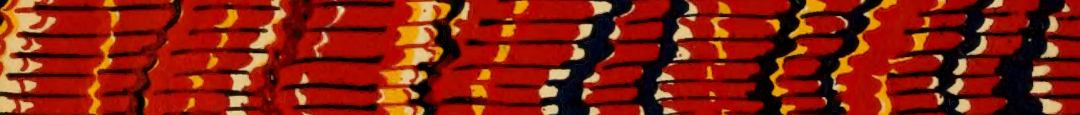

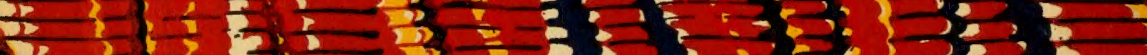

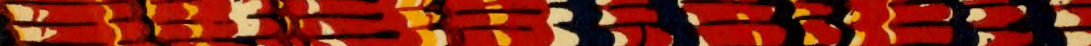

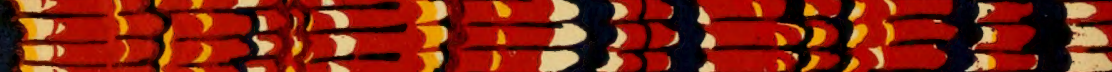

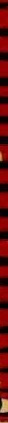

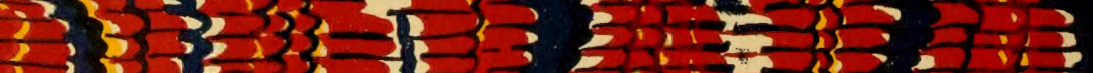

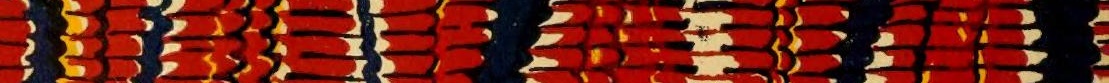

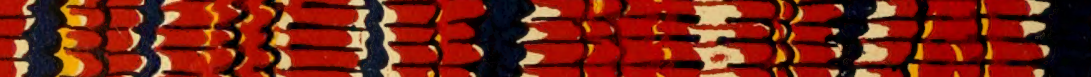

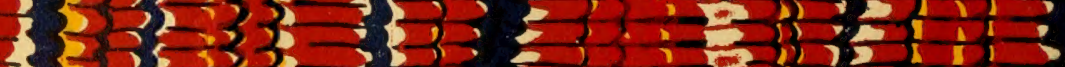

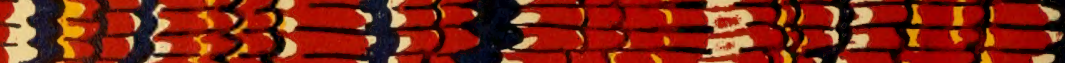

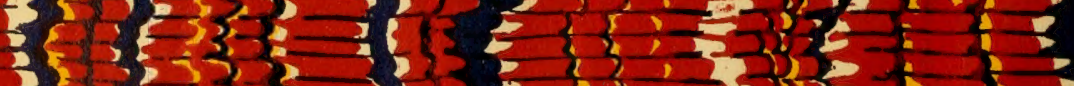

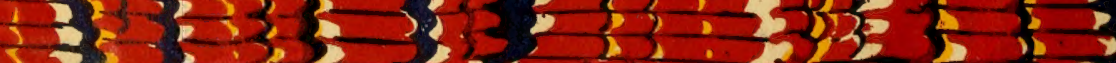

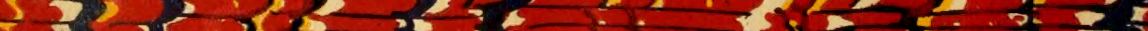


